\title{
Rohbraugh and deRosset on the Necessity of Origin
}

\author{
Ross Cameron and Sonia Roca
}

Forthcoming in Mind, 2006, vol. 115/458

Rohbraugh and deRosset (2004) propose a 'new' argument for the necessity of origin. The argument has 2 premisses, (T-IND) and (OU) below, which, when combined with the (necessity of the) necessity of distinctness, entail the necessity of origin.

(T-IND): Necessarily, given a table, $\mathrm{T}_{1}$, made from a hunk, $\mathrm{H}_{1}$, for any table, $\mathrm{T}$ which might be made from a hunk, $\mathrm{H}_{2}$, distinct from $\mathrm{H}_{1}$, it is also possible that both $\mathrm{T}_{1}$ is a table made from $\mathrm{H}_{1}$ and $\mathrm{T}_{2}$ is a table made from $\mathrm{H}_{2}$ (Rohbraugh and deRosset 2004, p.714).

(OU): Necessarily, if $\mathrm{T}_{1}$ is a table made from $\mathrm{H}_{1}$ and $\mathrm{T}_{2}$ is a table made from $\mathrm{H}_{2}$ and $\mathrm{H}_{1} \neq \mathrm{H}_{2}$, then $\mathrm{T}_{1} \neq \mathrm{T}_{2}$ (Rohbraugh and deRosset 2004, p.715).

The justification for (T-IND), according to Rohbraugh and deRosset, is what they call 'the independence principle':

(IP): 'processes that turn hunks into tables seem to enjoy a form of independence from one another. A process that turns one hunk into a table need not interfere with any other' (Rohbraugh and deRosset 2004, p.711).

Cameron (2005) proposed an interpretation of Kripke's footnote 56 argument for the essentiality of origin (Kripke 1980, p.114, fn.56) which is strikingly similar to the argument given by Rohbraugh and deRosset ${ }^{1}$, and we think that the criticisms that were raised there, as

well as some others, apply to Rohbraugh and deRosset's 'New Route'. Cameron

1- Rohbratgh and deRosset acknowledge their debt to Kripke's footnote (Rohbraugh and deRosset 2004, p.706, fn.1 and p.712, fn.12), but are careful not to directly attribute 
suggested that the crucial premise in Kripke's argument was that the ability to make a particular table from a particular hunk of wood cannot be affected by the making of any particular table from some other (wholly distinct) hunk of wood. (This corresponds to (IP).) Kripke's argument for the necessity of origin was then reconstructed as follows. If table $T_{1}$ is in fact made from hunk $H_{1}$ then $T_{1}$ cannot be made from a distinct hunk $\mathrm{H}_{2}$, for that would inhibit the possibility of making $\mathrm{T}_{1}$ from $\mathrm{H}_{1}$, since tables made from distinct hunks of wood must themselves be distinct. (This corresponds to the premise (OU).) So $\mathrm{T}_{1}$ must be made from $\mathrm{H}_{1}$; and since we are dealing with arbitrary tables and hunks the necessity of origin follows. Cameron's problem was this: there are two ways to understand the principle that the ability to make a particular table from a particular hunk of wood cannot be affected by the making of any particular table from a distinct hunk. There is a weak reading of the claim, which we will refer to as the No Limitation of Possibilities principle, (NLP) below:

(NLP): If it is possible to make a table $\mathrm{T}_{1}$ from $\mathrm{H}_{1}$ then no matter what table (if any) is made (in a given world) from $\mathrm{H}_{2}$ it should still be possible (from that world) to make $\mathrm{T}_{1}$ from $\mathrm{H}_{1}$.

And there is a stronger reading, corresponding to (T-IND), that says that if it is possible to make $T_{1}$ from $H_{1}$ then it is possible to make $T_{1}$ from $H_{1}$ and make any table from $\mathrm{H}_{2}$ that can be made from $\mathrm{H}_{2}$. We think that nothing Rohbraugh and deRosset have said in support of (IP) motivates the (T-IND) reading, but we grant that the motivation for (IP) supports (NLP).

There is also a third possible reading of (IP), a generalised compossibility claim (GC); and we are also granting that this reading is supported by intuitions underlying (IP).

(GC): If it is possible to make a table from $\mathrm{H}_{1}$ and it is possible to make a table from $\mathrm{H}_{2}$ then it is possible both to make a table from $\mathrm{H}_{1}$ and a table from $\mathrm{H}_{2}$.

What are our reasons for saying that (IP) does not support (T-IND)? To motivate (IP), Rohbraugh and deRosset first motivate the locality of prevention thesis by 
asking the following question: 'What does it take to prevent the production of a particular material object from a particular hunk of raw material?' (Rohbraugh and deRosset 2004, p.706). Let $\mathrm{T}_{1}$ be a table, and $\mathrm{H}_{1}$ the hunk of matter from which $\mathrm{T}_{1}$ originated. The answer they offer is that 'each factor which prevents $T_{1}$ from eventuating makes a difference to $\mathrm{H}_{1}$ or the people and tools involved in the productive effort' (Rohbraugh and deRosset 2004, p.707). This is the sense in which they claim that the preventions are local. The locality of prevention thesis, then, is a claim about what prevents $T_{1}$ from originating from the particular hunk $\mathrm{H}_{1}$; it is not a general claim about what prevents $\mathrm{T}_{1}$ from coming into existence at all. ${ }^{2}$ Thus, locality of prevention does not rule out the possibility that $\mathrm{T}_{1}$ originates from a distinct process in a world in which it has been prevented from originating from $\mathrm{H}_{1}$; that is,

(*) The intuitions supporting the locality of prevention thesis are compatible with intuitions for the contingency of origins.

To understand further the locality of prevention thesis, we need to introduce a distinction between prevention and exclusion. Rohbraugh and deRosset do not want to rule out that the same process may give rise to different entities ${ }^{3}$ : 'Running the process which actually leads from $\mathrm{H}_{1}$ to $\mathrm{T}_{1}$ in the presence of factors which do not locally infringe can still lead to $\mathrm{T}_{1}$ ' (Rohbraugh and deRosset 2004, p.708, our emphasis), but it needn't do so. They add 'All that is promised by the locality of prevention is that $T_{1}$ might still be the product in such a case. But, for all the principle tells us, it also might not' (Rohbraugh and deRosset 2004, p708). This requires a distinction between preventing $T_{1}$ originating from $\mathrm{H}_{1}$, and excluding $T_{1}$ originating from $\mathrm{H}_{1}$. If the process has not been infringed upon, but the outcome is $T_{3}$ instead of $T_{1 h}$, nothing prevents $T_{1}$ from originating from $\mathrm{H}_{1}$, meaning that it would still be possible to produce $T_{1}$ from $H_{1}$. The origination of $T_{3}$ from $H_{1}$, however, excludes $\mathrm{T}_{1}$ originating from $\mathrm{H}_{1}$, meaning that the actuality of producing

2 The question 'What prevents $\mathrm{T}_{1}$ from originating from $\mathrm{H}_{1}$ ?' can only be assumed to be equivalent to the question 'What prevents $\mathrm{T}_{1}$ from originating at all?' if we assume that $\mathrm{H}_{1}$ is the only possible origin for $\mathrm{T}_{1}$. To assume this would be to presuppose the Necessity of Origin (intended conclusion), and thus we think it is important to make it explicit all the time that the locality of prevention is a thesis about what it takes to prevent a given entity originating from a given process.

3 Their approach, after all, is meant to be different in kind to those that use the sufficiency of origin to prove the necessity of origin. 
$\mathrm{T}_{1}$ from $\mathrm{H}_{1}$ depends on the non-actuality of having produced $\mathrm{T}_{3}$ from $\mathrm{H}_{1}$. Two things seem to follow from Rohbraugh and deRosset's lack of commitment to the sufficiency of origins (SO). First, it is essential to the notion of prevention that it involves a change in the world other than a mere haecceitistic switch ${ }^{4}$. Second, there is, on their approach, room for exclusion without prevention. ${ }^{5}$

Let ' $\mathrm{Hi}{ }^{*}$ ' refer to the process ${ }^{6}$ of making a table from hunk $\mathrm{Hi}$, and $\left\langle\mathrm{Hi}^{*}, \mathrm{Tj}\right\rangle$ be the ordered pair of the process and its outcome. Since the notion of prevention essentially involves infringement upon the process, the locality of prevention thesis can only ground a principle stating independence of any two processes. (GC), restated now, is such a principle.

(GC): If it's possible to make a table from $\mathrm{H}_{1}$ and it is possible to make a table from $\mathrm{H}_{2}$ then it is possible both to make a table from $\mathrm{H}_{1}$ and a table from $\mathrm{H}_{2}$.

But the locality of prevention thesis does not motivate Particularized Compossibility, (PC) below; a principle stating independence of any two ordered pairs of processes and outcomes.

(PC): Any two ordered pairs of processes and outcomes, $<\mathrm{H}_{1}{ }^{*}, \mathrm{~T}_{1}>$ and $<\mathrm{H}_{2}{ }^{*}$, $\mathrm{T}_{2}>$, are compossible.

We have already seen why Rohbraugh and deRosset do not want to be committed to (PC). Given their non-commitment to (SO), there might be cases in which two ordered pairs exclude one another (without prevention). These are the cases in which $\mathrm{H}_{1} *=\mathrm{H}_{2}{ }^{*}$, but $\mathrm{T}_{1} \neq \mathrm{T}_{2}$. That is: same process, different outcome.

We have already argued for $(*)$ : the claim that the intuitions supporting the locality of prevention thesis are compatible with intuitions for the contingency of origins. This is to say that such a thesis is compatible with a different kind of exclusion;

4 As they say: 'any case in which some factor prevents the production of $\mathrm{T}_{1}$ from $\mathrm{H}_{1}$ must differ from actual circumstances with respect to properties of either $\mathrm{H}_{1}$ or other elements of the process by which $\mathrm{T}_{1}$ actually emerged' (Rohbraugh and deRosset 2004, p707).

5 As would be the case if sufficiency of origins was false.

6 Processes must be individuated independently of their outcomes, otherwise (SO) is trivially true. 
namely, that in which $\mathrm{T}_{1}=\mathrm{T}_{2}$, but $\mathrm{H}_{1} * \neq \mathrm{T}_{2} *$ : same outcome, different process.

The first kind of exclusion is the one Rohbraugh and deRosset want to leave open so as not to be committed to (SO). The second kind of exclusion is the one they need to leave open, in order not to beg the question.

(T-IND) is in between (GC) and (PC) in strength. We clearly see how locality of prevention supports (GC). We have seen that Rohbraugh and deRosset intend the locality of prevention not to establish (PC), given that they do not want to rule out the first kind of exclusion above. But we don't see how the locality of prevention can motivate a middle course independence principle like (T-IND), compatible with the first kind of exclusion, but incompatible with the second.

(T-IND) says that, given the pair $<\mathrm{H}_{1}{ }^{*}, \mathrm{~T}_{1}>$ then, given any process $\mathrm{H}_{2}{ }^{*}$, it happens that any pair $\left\langle\mathrm{H}_{2}{ }^{*}, \mathrm{x}>\right.$ such that $\mathrm{x}$ is a possible outcome of $\mathrm{H}_{2}{ }^{*}$ is compossible with $<\mathrm{H}_{1}{ }^{*}, \mathrm{~T}_{1}>$. This implies the impossibility of $\left\langle\mathrm{H}_{2}{ }^{*}, \mathrm{~T}_{1}>\right.$. But, according to our $\left(^{*}\right)$, its possibility is not ruled out by the locality of prevention, and hence not by any independence principle grounded on it.

Thus (T-IND) is stronger than what can be supported by locality of prevention (thus by (IP)); and it is stronger in an objectionable way. Our objection is that it begs the question; for the extra strength that (T-IND) has with respect to (GC) can come only from assuming the necessity of origin.

Rohbraugh and deRosset make an attempt at addressing this worry. They write that 'someone who wants to claim that we can make $\mathrm{H}_{2}$ into $\mathrm{T}_{1}$ needs to explain why we could not also run the process which in fact turned $\mathrm{H}_{1}$ into $\mathrm{T}_{1}$ or why that process could not result in $\mathrm{T}_{1}$ ' (Rohbraugh and deRosset 2004, p.716). This is the wrong challenge. Given the truth of (NLP) we think that you could still run the process, and it could still result in $\mathrm{T}_{1}$; both are possibilities in that world. However the actuality of making $\mathrm{H}_{2}$ into $\mathrm{T}_{1}$ excludes the actuality of making $\mathrm{H}_{1}$ into $\mathrm{T}_{1}$. They also say that 'Either sort of explanation would appear to violate the locality of prevention' (Rohbraugh and deRosset 2004, p.716). This is not so. As we have argued, locality of prevention is a thesis supporting the independency of processes. If we make $\mathrm{H}_{2}$ into $\mathrm{T}_{1}$, the locality of prevention ensures that we can still, in that world, make $\mathrm{H}_{1}$ into a table: no violation here. Exclusion of the second kind ensures then that such a table will not be $T_{1}$ : but there is no violation here either; it is simply a case of exclusion without prevention. 
Although it is true that the kind of exclusion that the non-sufficiency of origins requires is different from that required by the contingency of origins, we see no reason why the second kind should be more problematic than the first. Since Rohbraugh and deRosset must allow for exclusions of the first kind, and since the second kind no more violate the locality of prevention than the first, we do not see how they can rule out the second without assuming that one of the pairs involved is impossible (in the example above $<\mathrm{H}_{2}{ }^{*}, \mathrm{~T}_{1}>$ ), which would simply be to beg the question. $^{7}$

Arché: AHRB research center for the philosophy of

ROSS CAMERON

Logic, Language, Mathematics and Mind.

University of St Andrews

rpc2@st-andrews.ac.uk

Logos: Research Group in Logic, Language and Cognition

SONIA ROCA

Department of Logic, History and Philosophy of Science

University of Barcelona

Arché: AHRB research center for the philosophy of

Logic, Language, Mathematics and Mind.

University of St Andrews

sonia@ rocaroyes.net

\section{References}

Cameron, Ross 2005: 'A Note on Kripke's Footnote 56 Argument for the Essentiality of Origin'. Ratio, XVIII(3), pp262-275.

Rohbraugh, Guy and deRosset, Louis 2004: 'A New Route to the Necessity of Origin'. Mind, 133, pp705-725.

Kripke, Saul 1980: Naming and Necessity. Oxford: Blackwell.

7 We would like to thank the members of both Arché: The AHRB Research Centre for the philosophy of Logic, Language, Mathematics and Mind (University of St.Andrews) and LOGOS-Grup de Recerca en Lògica, Llenguatge i Cognició (Universitat de Barcelona). 